\title{
Primary Cutaneous Solitary Fibrous Tumor on the Back
}

\author{
Sung Soo Han, Se Kwang Park, Ju Wang Jang, Tae Lim Kim, Hyun Seok Choi, Hyung Kwon Park, \\ Hyun-Min Seo, Joung Soo Kim \\ Department of Dermatology, Hanyang University Guri Hospital, Guri, Korea
}

Solitary fibrous tumors (SFT) are uncommon mesenchymal tumors. SFT have several synonyms including localized fibrous tumor, benign mesothelioma, localized fibrous mesothelioma, and submesothelial fibroma. SFT usually occur in the pleura or other serosal surfaces, but SFT can also develop in extrapleural areas including the nasal cavity, orbit, retroperitoneum, and pelvis. Cutaneous SFT is extremely rare, and more likely to occur in the head and neck region. Histologically, this tumor can mimic a variety of benign and malignant tumors such as dermatofibroma, dermatofibrosarcoma protuberans, spindle cell lipoma or other mesenchymal tumors. Most cases of SFT show non-aggressive clinical courses, with low recurrence rates. Herein, we describe a case of primary cutaneous SFT which presented with huge mass on the back. (Ann Dermatol 32(2) 155 158, 2020)

\section{-Keywords-}

Back, Skin, Solitary fibrous tumors

\section{INTRODUCTION}

Solitary fibrous tumors (SFT) is a rare tumor of mesenchy-

Received August 7, 2017, Revised January 4, 2019, Accepted for publication February 7, 2019

Corresponding author: Joung Soo Kim, Department of Dermatology, Hanyang University Guri Hospital, 153 Gyeongchun-ro, Guri 11923, Korea. Tel: 82-31-560-2286, Fax: 82-31-557-4872, E-mail: tuentuen@hanyang. ac. kr

ORCID: https://orcid.org/0000-0002-3014-9645

This is an Open Access article distributed under the terms of the Creative Commons Attribution Non-Commercial License (http://creativecommons. org/licenses/by-nc/4.0) which permits unrestricted non-commercial use, distribution, and reproduction in any medium, provided the original work is properly cited.

Copyright (c) The Korean Dermatological Association and The Korean Society for Investigative Dermatology mal origin and most commonly involves the pleura ${ }^{1}$. However, the presence of SFT has been reported rarely in various parts of body. It is usually located in the liver, kidney, thyroid, nervous system or skin if it develops outside of thoracic cavity. It is known that the SFT that develops primarily in the skin is clinically similar to the cyst or lipoma and appears as a nonspecific single nodule or subcutaneous mass ${ }^{2}$. Histologically, SFT may be difficult to diagnose because they show various histopathologic features and are characterized by solid spindle cell, diffuse sclerosing, fascicular, storiform, herringbone, angiofibromatous pattern, and so-called 'patternless pattern' ${ }^{3}$. Therefore, it is necessary to differentiate from various tumors such as dermatofibroma, dermatofibrosarcoma protuberans, hemangiopericytoma, myofibroma, and spindle cell lipoma ${ }^{1}$.

We experienced a rare case of SFT presented with a large subcutaneous mass on the skin.

\section{CASE REPORT}

A 74-year-old male presented with slowly growing subcutaneous mass on his upper back for 10 years. He did not complain for pain or other subjective symptoms. Physical examination revealed a hemispheric subcutaneous mass with a diameter of about $5 \mathrm{~cm}$ (Fig. 1). It palpated as a solid, mobile mass. There was no tenderness at the time of presentation. On histologic examination, epidermis and dermis showed no specific findings. Solid mass without encapsulation was found on subcutaneous layer (Fig. 2). Fibrous matrix was observed inside of tumor. There were a part of relatively dense cells and a part consisted of cells with low cellularity inside the fibrous matrix. Proliferation of the blood vessels was observed. At high magnification view, spindle cells were composed of "patternless" swirling patterns and showed some spiral patterns. Area with less cellularity was mainly consisted of hyalinized collagen fibers. Irregularly extended blood vessels with thin 

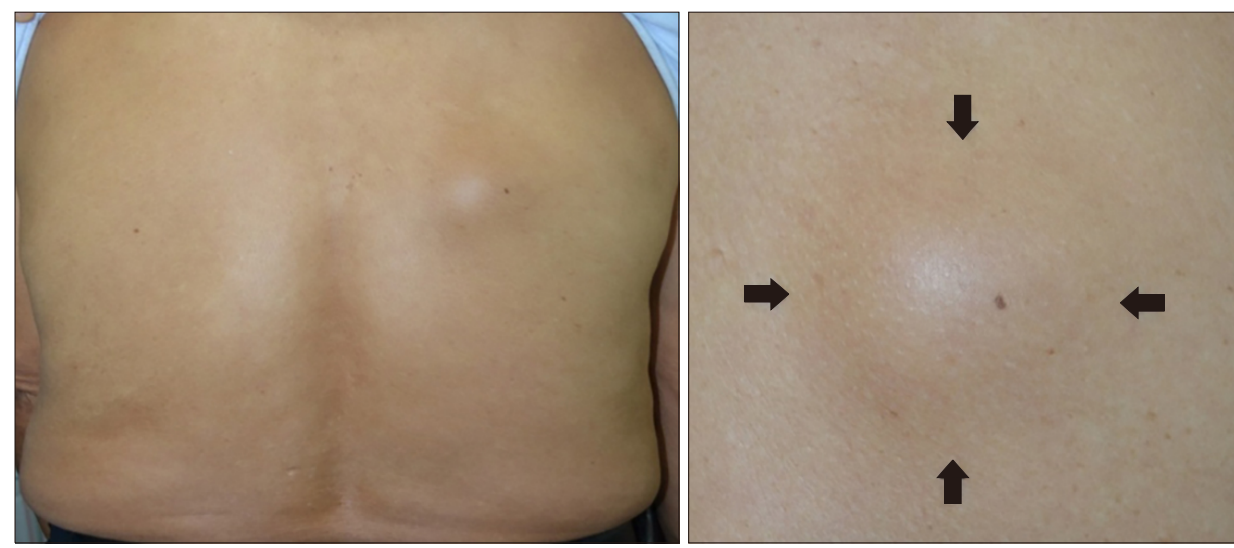

Fig. 1. Solitary, dome-shaped subcutaneous mass on patient's right back.
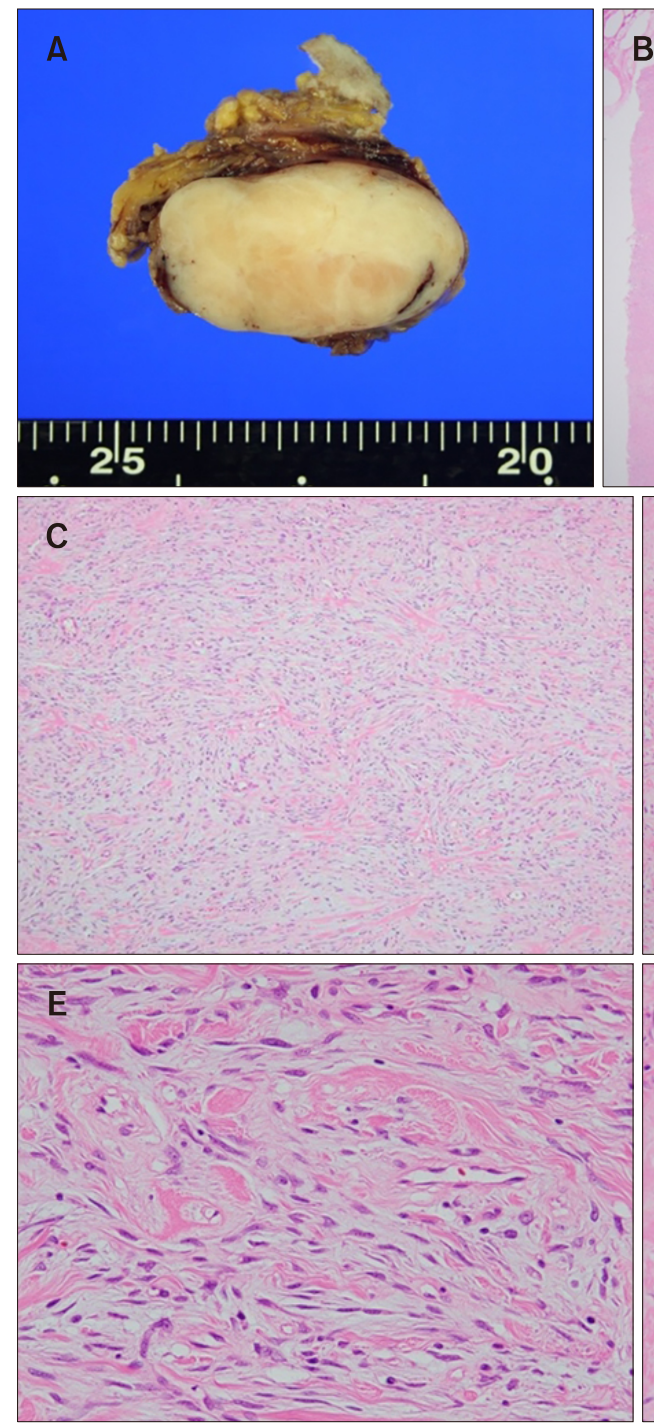

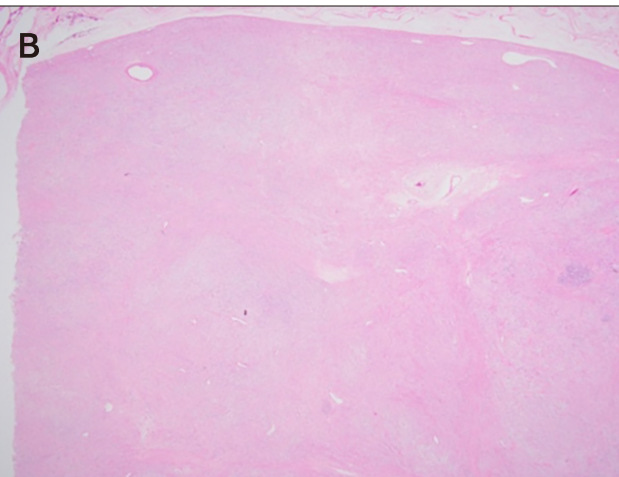

D

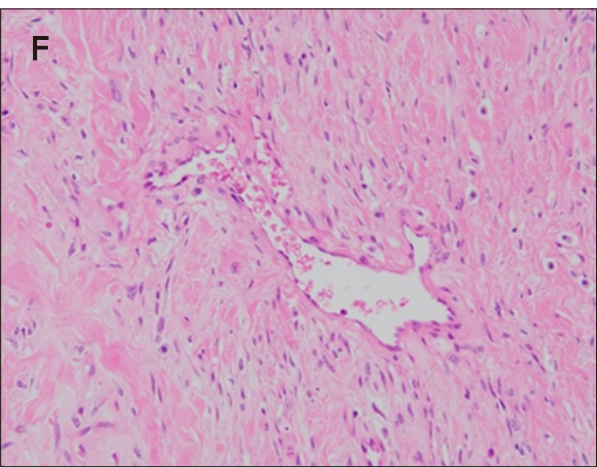

Fig. 2. (A) Cut section of the tumor showed an ovoid, well defined white-tan solid mass measuring $50 \times$ $35 \times 28 \mathrm{~mm}$ in size. (B) A spheroid, well-circumscribed tumor composed of alternating hypercellular and fibrous hypocellular areas was observed in the subcutis $(\mathrm{H} \& \mathrm{E}, \times 40)$. (C) In the highly cellular areas, spindle-shaped cells were present in short interlacing fascicles, mixed with interstitial fibrous tissue (H\&E, $\times 100$ ). (D) In hypocellular foci, interspersed collagen fibers were mainly seen $(\mathrm{H} \& \mathrm{E}, \times 100)$. (E) Many of the cells had enlarged vesicular nuclei with inconspicuous nucleoli $(\mathrm{H} \& \mathrm{E}, \times 400)$. (F) Staghorn and ectatic blood vessels were found in some areas $(H \& E, \times 200)$. walls and some staghorn-shaped vessels were found (Fig. 2). The spindle cells had a pale-coloredvesicular nucleus and no cellular dysplasia or mitosis was observed. Immunohistochemical stains revealed positivity for CD34, Bcl-2,
CD99, and factor XIIla. Tumor cells did not stained for smooth muscle actin (SMA) and S-100 (Fig. 3). Based on the histologic findings of the excision biopsy specimen, SFT of the skin was diagnosed. The tumor didn't recur af- 

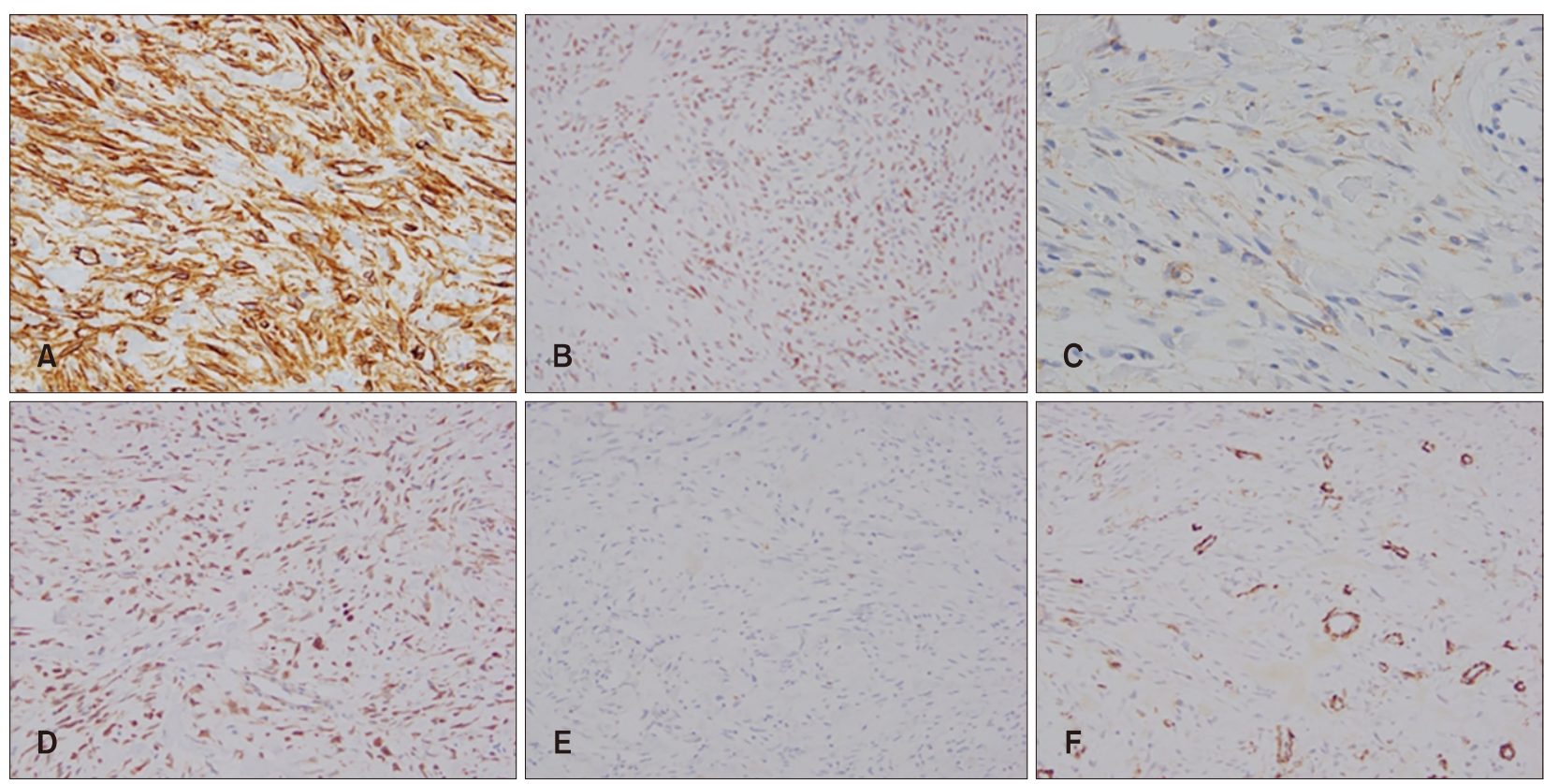

Fig. 3. Immunohistochemical staining was performed for smooth muscle actin (SMA), S-100, CD34, BCl-2, CD99 and factor XIIla. The tumor cells demonstrated positivity for CD34, factor XIIla, CD99 and BCl-2 (A: CD34, ×200; B: factor XIIla, $\times 100$; C: CD99, $\times 100$; D: $\mathrm{Bcl}-2, \times 100)$. However, S-100 and SMA staining were negative in tumor cell $(\mathrm{E}: \mathrm{S}-100, \times 100 ; \mathrm{F}: \mathrm{SMA}, \times 100)$.

Table 1. Clinicopathologic features of previously reported cases of primary cutaneous SFTs

\begin{tabular}{|c|c|c|c|c|c|}
\hline Reference & $\begin{array}{l}\text { Sex/age } \\
(y r)\end{array}$ & Site & $\begin{array}{l}\text { Treatment and } \\
\text { follow-up time }\end{array}$ & Positive IHC & Negative IHC \\
\hline $\begin{array}{l}\text { Okamura } \\
\text { et al. }\end{array}$ & $\mathrm{F} / 37$ & Scalp & $\mathrm{LE}, 10 \mathrm{mo}$ & CD34, vimentin, collagen IV & $\begin{array}{l}\text { CD68, desmin, SMA, } \\
\text { cytokeratin, EMA, S-100 }\end{array}$ \\
\hline $\begin{array}{l}\text { Cowper } \\
\text { et al. }\end{array}$ & $\begin{array}{l}M / 63, F / 46 \\
M / 38\end{array}$ & $\begin{array}{l}\text { Posterior neck (2), } \\
\text { occipital region (1) }\end{array}$ & $\mathrm{LE}$, mean 6 mo & CD34, vimentin & S-100, cytokeratin, EMA \\
\hline $\begin{array}{l}\text { Hardisson } \\
\text { et al. }\end{array}$ & $\mathrm{F} / 56$ & Cheek & $\mathrm{LE}, 16 \mathrm{mo}$ & CD34, vimentin, bcl-2 & $\begin{array}{l}\text { S-100, desmin, factor VIII, } \\
\text { MSA, CD68, type IV } \\
\text { collagen }\end{array}$ \\
\hline $\begin{array}{l}\text { Wood } \\
\text { et al. }\end{array}$ & $\begin{array}{l}M / 66, M / 55 \\
M / 44, F / 88 \\
F / 55, F / 25\end{array}$ & $\begin{array}{l}\text { Thigh (3), lower } \\
\text { extremitiy (2), } \\
\text { abdomen (1) }\end{array}$ & NA & $\begin{array}{l}\text { CD34 (6/6), bcl-2 (5/5), } \\
\text { CD99 (3/4) }\end{array}$ & Factor XIIIa, S-100 \\
\hline $\begin{array}{l}\text { Soldano and } \\
\text { Meehan }^{6}\end{array}$ & $F / 26, F / 35$ & $\begin{array}{l}\text { Lateral abdomen, } \\
\text { forehead }\end{array}$ & $\mathrm{LE}$, mean $14 \mathrm{mo}$ & CD34, vimentin, focal CD99 & $\begin{array}{l}\text { CAM 5.2, AE1/AE3, EAB-903, } \\
\text { EMA, SMA }\end{array}$ \\
\hline Our case & $M / 74$ & Back & $\mathrm{LE}, 12 \mathrm{mo}$ & $\begin{array}{l}\text { CD34, bcl-2, CD99, factor } \\
\text { XIIla }\end{array}$ & S-100, SMA \\
\hline
\end{tabular}

SFT: solitary fibrous tumor, IHC: Immunohistochemistry, F: female, LE: local excision, SMA: smooth muscle actin, EMA: epithelial membrane antigen, M: male, MSA: muscle-specific actin, NA: not available.

ter one year following-up. We received the patient's consent form about publishing all photographic materials.

\section{DISCUSSION}

SFT is a relatively rare mesenchymal tumor that has been described for the first time as a neoplasm composed of spindle-shaped cells in the pleura by Klemperer and Rabin ${ }^{4}$.
However, it is very rare that a SFT primarily occurs in the skin. Okamura et al. ${ }^{5}$ reported the first case of SFT on skin in 1997. According to a study of 17 cases of SFT on the skin, asymptomatic subcutaneous masses similar to cysts or lipomas were usually found on head and neck ${ }^{6}$. Histologically, it is composed of spindle-shaped cells and it is observed that the pattern of hemangiopericytoma-like appearance, spiral pattern, and fibrous spindle cell pro- 
liferation are expressed as 'patternless pattern'7. It is also characterized by alternating areas of high and low cell density $^{8}$. In immunohistochemical staining, CD34 is mostly positive but it is not a specific finding. Bcl-2, CD99, factor XIIla staining may be helpful in diagnosis (Table 1$)^{7}$. Generally, the SFT is benign but local recurrence may occur and periodic follow-up is required ${ }^{9}$. In some cases, malignant transformation may be seen. There are some opinions to categorize SFT as borderline tumors ${ }^{1}$. In cases of tumor size greater than $5 \mathrm{~cm}$, infiltrative growth, high cellularity, polymorphism, necrosis, and mitosis more than 4 10 per high power field occur, malignancy can be suspected ${ }^{1}$.

In this case, SMA stain was negative so myofibroma could be excluded. Myofibroma shows an arrangement of interlacing fascicles of spindle-shaped cells resembling myofibroblasts ${ }^{10}$. Spindled cells express vimentin and SMA and are usually negative for desmin ${ }^{10}$. Negative findings on S-100 could exclude tumors of neural origin such as schwannomas. CD34 staining was generally positive, but the demarcation of tumor was fairly good. And histologic findings were more various than those of spindle-shaped cells with uniform morphology. Therefore, it was possible to distinguish the dermatofibrosarcoma protuberance. In addition, Bcl-2, factor XIIla and CD99 immunohistochemical staining showed positive findings, which is consistent with SFT. We report a rare case of primary SFT on back that was diagnosed by excisional biopsy, showing unusual clinical features.

\section{CONFLICTS OF INTEREST}

The authors have nothing to disclose.

\section{ORCID}

Sung Soo Han, https://orcid.org/0000-0002-1742-0402
Se Kwang Park, https://orcid.org/0000-0002-2342-9577 Ju Wang Jang, https://orcid.org/0000-0001-5885-4250 Tae Lim Kim, https://orcid.org/0000-0002-2639-1973 Hyun Seok Choi, https://orcid.org/0000-0002-5963-4820 Hyung Kwon Park, https://orcid.org/0000-0002-3981-2896 Hyun-Min Seo, https://orcid.org/0000-0002-6897-494X Joung Soo Kim, https://orcid.org/0000-0002-3014-9645

\section{REFERENCES}

1. Erdag G, Qureshi HS, Patterson JW, Wick MR. Solitary fibrous tumors of the skin: a clinicopathologic study of 10 cases and review of the literature. J Cutan Pathol 2007; 34:844-850.

2. Kang TW, Kim HJ, Kim YC, Kim SC. A case of solitary fibrous tumor that developed on the scalp. Korean J Dermatol 2009;47:615-617.

3. Moran CA, Suster S, Koss MN. The spectrum of histologic growth patterns in benign and malignant fibrous tumors of the pleura. Semin Diagn Pathol 1992;9:169-180.

4. Klemperer P, Rabin CB. Primary neoplasms of the pleura: a report of five cases. Arch Pathol 1931;11:385-412.

5. Okamura JM, Barr RJ, Battifora H. Solitary fibrous tumor of the skin. Am J Dermatopathol 1997;19:515-518.

6. Soldano AC, Meehan SA. Cutaneous solitary fibrous tumor: a report of 2 cases and review of the literature. Am J Dermatopathol 2008;30:54-58.

7. Terada T. Solitary fibrous tumor of the shoulder showing diverse distinct histologic patterns. Int J Dermatol 2011;50: 208-211.

8. Ali SZ, Hoon V, Hoda S, Heelan R, Zakowski MF. Solitary fibrous tumor. A cytologic-histologic study with clinical, radiologic, and immunohistochemical correlations. Cancer 1997;81:116-121.

9. Omori $Y$, Saeki $H$, Ito $K$, Matsuzaki $H$, Tokita $M$, Itoh $M$, et al. Solitary fibrous tumour of the scalp. Clin Exp Dermatol 2014;39:539-541.

10. Kye H, Kwon IH, Seo SH, Ahn HH, Kye YC, Choi JE. Adult multiple myofibromas on an atrophic patch on the thigh. Ann Dermatol 2015;27:622-623. 